\title{
THE COMPARATIVE ANALYSIS OF HYDRODYNAMIC PRESSURES IN CYLINDRICAL TANKS
}

\author{
Bogdan Alexandru BUTNARU - PhD Student, Technical University of Civil Engineering Bucharest, Department \\ of Strength of Materials, Bridges and Tunnels, e-mail: bogo_bogdan@yahoo.com \\ Mirela ȘANDRU - PhD Student, Technical University of Civil Engineering Bucharest, Department of Strength of \\ Materials, Bridges and Tunnels, e-mail: mirela.esandru@yahoo.com \\ Dumitrel FURIȘ - Professor, PhD, Technical University of Civil Engineering Bucharest \\ Dan Ilie CREȚU - Professor, PhD, Technical University of Civil Engineering Bucharest, e-mail: cretud@utcb.ro
}

\begin{abstract}
This article presents a comparative study of the values of hydrodynamic pressure and their resultants occurred during the seismic action using P100-1/2013 technical rules and the relations defined in the papers: [1], [3], [5] and the Romanian standard [2] SR EN 1998-4 (silos, tanks and pipelines), which is implemented in Romania. Two cylindrical tanks placed in the same seismic zone have been chosen, with the same amount of storage (about $5000 \mathrm{~m}^{3}$ ), but of different geometries, to illustrate the influence of hydrodynamic pressures on the construction size (long and short wall behavior) as a function of ratio of the fluid height on the cylinder radius and ratio of corner period on the eigenperiod of the fluid mass. Also in the analyses, in order to evaluate the hydrodynamic convective pressure both the fundamental period of oscillation of the fluid mass and the first ten periods of oscillation were used.
\end{abstract}

Keywords: seism, impulsive pressure, convective pressure, Housner, Epstein, Eurocode

\section{Introduction}

The study of the behavior and the evaluation of response of cylindrical structures that store liquid has always been a complex and difficult problem because the modeling phenomena of interaction between fluid and structure as well as the assembly structure-fluid-foundation soil is very difficult to be put in practice to obtain satisfactory results.

In solving this problem numerous methods of calculation have been developed over time which have been covered by a series of scientific works that are the basic rules of designing tanks that store fluids.

The initiator of the hydrodynamic pressure problem was Westergaard (1933), who presented solutions to evaluate the hydrodynamic pressure on a vertical upstream wall of a dam subjected to horizontal harmonical accelerations. In the case of the cylindrical fluid storage tanks, Housner (1954) is considered to be the initiator, because he created simple dynamic models based on the experiments carried out and he offered solutions to this problem.

Subsequently, numerous authors like Epstein, Veletsos, Yang et al. Yamamoto, tried to improve Housner's model for all types of tanks. These calculation models are detailed in the paper [5].

The purpose of this paper is to perform a comparative analysis between the tanks size and the variation of hydrodynamic pressures considering provisions of the European standard [2] and those indicated in [1], [3], [5].

\section{Models and relationships for the evaluation of the hydrodynamic pressure}

In order to determine a satisfactory response of structures to seismic action many factors must be taken into account of which we can mention [1]:

- the correctness of the seismic action that depends on the possibilities of recording and the equipment performance; 
- the possibility of proper modeling of the elastic and damping characteristics of the structure's material, of the stored fluids, and of the foundation soil;

- methods and meshing smoothness used in the composition of the dynamic model that is under analysis;

- schematization of the links between structural components of the system and of the link of the structural system with the foundation, the latter being an essential element to achieve good accuracy results;

- methods of solving equations of motion: analytical (situations where analytical integration is not possible) and numerical which are effective in solving many problems, however they remain approximate methods.

Although determining the dynamic response involves confrontation with some difficulties, in time computational methods that consider more or less the response type of this type of constructions have been developed.

The first method was developed by Housner [3] in the form of simple dynamic models that were based on measurements which he had made on the ground. The reservoir-fluid assemble was treated in dynamic systems with two or more degrees of freedom to which certain mass and stiffness characteristics were assigned.

Figures 1, 2 and 3 show the equivalent mechanical models used by Housner and Epstein:
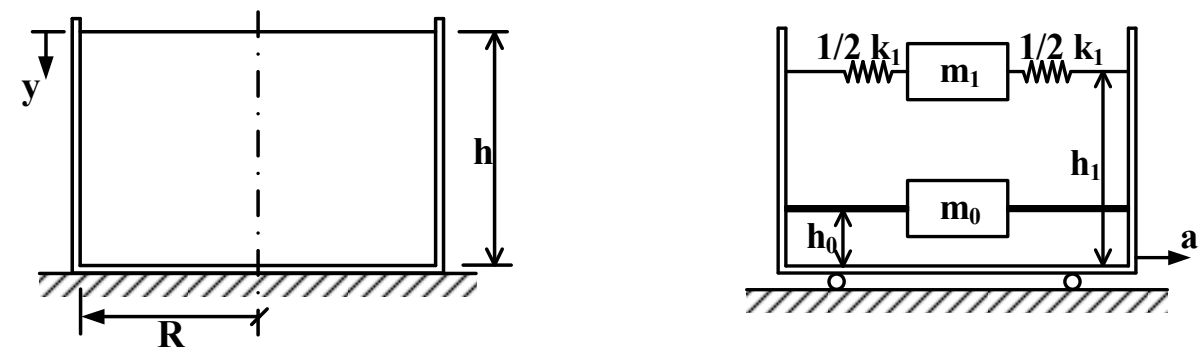

Fig. 1 - The mechanical equivalent system of Housner's model [3]

where [3]:

$\mathrm{y}-$ measured distance below the free surface of the liquid to reservoir bottom;

$\mathrm{h}$ - liquid depth at reservoir bottom;

$\mathrm{R}$ - radius of the cylinder;

a - horizontal ground acceleration;

$\mathrm{k}_{1}$ - elastic spring constant that makes mass $\mathrm{m}_{1}$ has its eigenperiod of the first mode of vibration of the fluid;

$\mathrm{h}_{0}, \mathrm{~h}_{1}-$ heights corresponding to masses $\mathrm{m}_{0}$ and $\mathrm{m}_{1}$ versus reservoir bottom;

$\mathrm{m}_{0}, \mathrm{~m}_{1}-$ impulsive and convective masses.
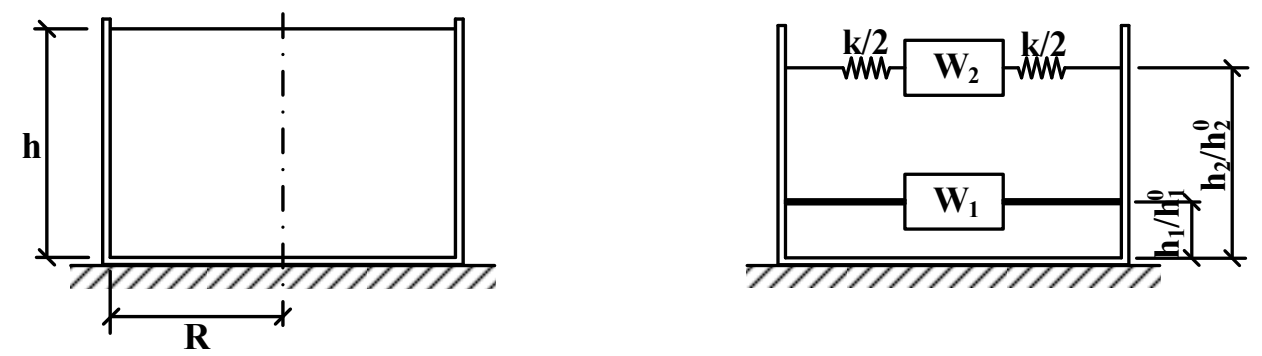

Fig. 2 - Epstein tank model for ratio $h / R \leq 1,5$ [5] 

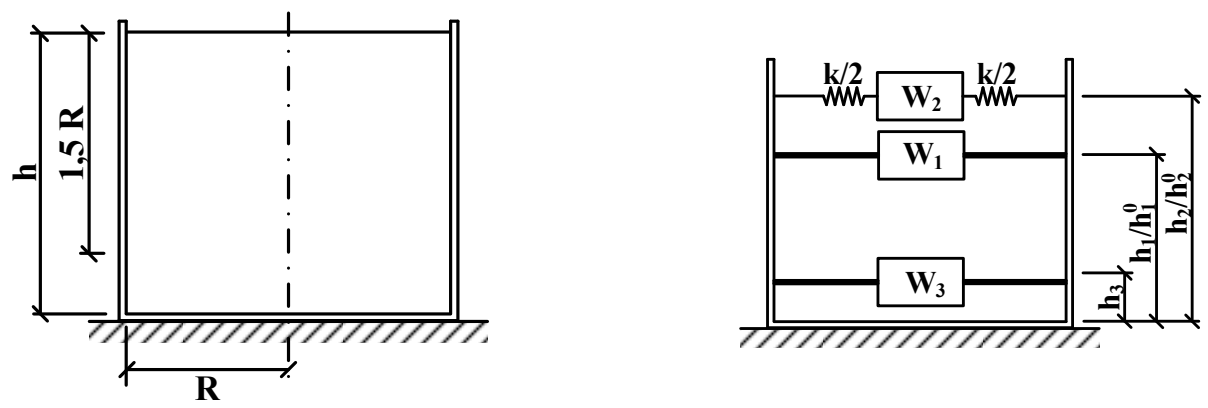

Fig. 3 - Epstein tank model for ratio h/R $>1,5[5]$

where [5]:

$\mathrm{W}_{1}, \mathrm{~W}_{3}$ - weight of impulsive mass;

$\mathrm{W}_{2}$ - weight of convective mass;

$\mathrm{h}_{1}, \mathrm{~h}_{2}, \mathrm{~h}_{3}, \mathrm{~h}_{1}{ }^{0}, \mathrm{~h}_{2}{ }^{0}$ - heights defined in paper [5].

Based on these models we can calculate total horizontal force and bending moment acting on the tank wall and the foundation.

The second method (which is also the most used) involves the evaluation of the hydrodynamic overpressures occurring during the earthquake considering some simplifying hypotheses [1]:

- the fluid movement is assumed continous, not permanent, irrotational and with free surface;

- the fluid is considered homogeneous, incompressible and without viscosity;

- the tank structure is rigid (with deformable contour) in relation to the fluid and is integral with the foundation, aiming his movements;

- the seismic motion occurs in one direction (the dominant), its characteristics are known through recorded or simulated accelerograms.

It is admitted that there is a potential function of the velocities of the fluid particles, as a function of time and space, that satisfies the Laplace equation and the limit conditions on the boundary domain occupied by the fluid and the hydrodynamic pressure is expressed according to this [1]:

where:

$$
\mathrm{p}=-\rho_{\mathrm{f}} \cdot \frac{\partial \Phi}{\partial \mathrm{t}}
$$

$\mathrm{p}$ - hydrodynamic pressure;

$\rho_{\mathrm{f}}-$ density of the fluid;

$\mathrm{t}$ - time;

$\Phi-$ potential function.

For cylindrical tanks, using cylindrical coordinates, Laplace equation has the form [1]:

$$
\Delta[\Phi(\mathrm{r}, \theta, \mathrm{z}, \mathrm{t})]=0
$$

where:

r, $\theta, \mathrm{z}$ - cylindrical coordinates: radial, circumferential, vertical;

$$
\Delta[\Phi(\mathrm{r}, \theta, \mathrm{z}, \mathrm{t})]=\frac{\partial^{2} \Phi}{\partial \mathrm{r}^{2}}+\frac{1}{\mathrm{r}} \frac{\partial \Phi}{\partial \mathrm{r}}+\frac{1}{\mathrm{r}^{2}} \frac{\partial^{2} \Phi}{\partial \theta^{2}}+\frac{\partial^{2} \Phi}{\partial \mathrm{z}^{2}}
$$


The boundary conditions on the border domain occupied by the fluid can be expressed mathematically [1]:

- $\quad$ null speed condition at fluid contact with bottom plate:

$$
\frac{\partial \Phi}{\partial z}=0
$$

- condition that the velocity of the fluid particle at contact with the walls to be equal to the speed induced by the earthquake to walls:

$$
\frac{\partial \Phi}{\partial \mathrm{z}}=\mathrm{K} \cdot \mathrm{u}_{\mathrm{g}}
$$

- $\quad$ linearized boundary condition for the free surface of fluid:

$$
\frac{\partial^{2} \Phi}{\partial \mathrm{r}^{2}}+\mathrm{g} \frac{\partial \Phi}{\partial \mathrm{z}}=0
$$

The integration of Laplace equation with the boundary conditions presented above allows defining the hydrodynamic pressure.

The third method (which is more rigorous) consists of mesh assembly of the structure-fluidfoundation soil in finite elements and complete treatment of the interaction phenomena. However there are some difficulties in applying this, caused by [1]:

- the necessity of analyzing it on substructures (the elastic tank substructure, the fluid substructure, the foundation soil substructure) and expressing the correct boundary conditions at the interface of the substructures;

- the existence of difficulties in defining damping matrices of structure, of fluid and especially of foundation soil;

- in the case of large amplitude oscillations, the phenomenon becomes nonlinear and the difficulties in solving the problem increase significantly.

Most of the scientific works dedicated to this problem, including the existing seismic design codes are based on the second method presented. Once the hydrodynamic pressure defined, one can move on to calculate the state of internal forces and deformations considering that pressure is acting statically on the structure.

Because Epstein's model (with two or three masses) from paper [5] is a simplified one, it does not allow the calculation and distribution of hydrodynamic pressure on the wall and foundation plate of the tank, but only the resultants of them, as: forces of inertia caused by the impulsive mass, convective mass and global moments.

In order to achieve the calculation study, relations for hydrodynamic pressure were considered, that were defined in the literature [1], [2], [3], as in the tables below:

\begin{tabular}{|c|l|}
\hline \multicolumn{2}{|c|}{ Dinamica plăcilor plane și curbe [1] } \\
\hline $\begin{array}{c}\text { impulsive pressure } \\
\text { at wall }\end{array}$ & $\mathrm{p}_{\mathrm{i}}(\mathrm{x}, \theta)=\mathrm{c}_{\mathrm{si}} \cdot \gamma_{\mathrm{f}} \cdot \mathrm{H} \cdot \mathrm{F}_{1} \cdot \cos (\theta)$ \\
\hline $\begin{array}{c}\text { impulsive pressure } \\
\text { on bottom }\end{array}$ & $\mathrm{p}_{\mathrm{i}}(\mathrm{x}, \theta)=\mathrm{c}_{\mathrm{si}} \cdot \gamma_{\mathrm{f}} \cdot \mathrm{H} \cdot \mathrm{F}_{2} \cdot \cos (\theta)$ \\
\hline $\begin{array}{c}\text { convective pressure } \\
\text { at wall }\end{array}$ & $\mathrm{p}_{\mathrm{c}}(\mathrm{x}, \theta)=\mathrm{c}_{\mathrm{sc}} \cdot \gamma_{\mathrm{f}} \cdot \mathrm{H} \cdot \mathrm{F}_{3} \cdot \cos (\theta)$ \\
\hline $\begin{array}{c}\text { convective pressure } \\
\text { on bottom }\end{array}$ & $\mathrm{p}_{\mathrm{c}}(\mathrm{x}, \theta)=\mathrm{c}_{\mathrm{sc}} \cdot \gamma_{\mathrm{f}} \cdot \mathrm{H} \cdot \mathrm{F}_{4} \cdot \cos (\theta)$ \\
\hline \multicolumn{2}{|c|}{ pressure terms are defined in work $[1]$} \\
\hline
\end{tabular}


Table 2

\begin{tabular}{|c|c|}
\hline \multicolumn{2}{|c|}{ SR EN 1998-4 [2] } \\
\hline $\begin{array}{c}\text { impulsive pressure } \\
\text { at wall }\end{array}$ & $\mathrm{p}_{\mathrm{i}}(\varsigma, \theta, \mathrm{t})=\mathrm{C}_{\mathrm{i}}(\varsigma) \cdot \rho \cdot \mathrm{H} \cdot \cos (\theta) \cdot \mathrm{A}_{\mathrm{g}}(\mathrm{t})$ \\
\hline $\begin{array}{c}\text { impulsive pressure } \\
\text { on bottom }\end{array}$ & $\mathrm{p}_{\mathrm{i}}(\xi, \theta, \mathrm{t})=\mathrm{C}_{\mathrm{i}}(\xi) \cdot \rho \cdot \mathrm{H} \cdot \cos (\theta) \cdot \mathrm{A}_{\mathrm{g}}(\mathrm{t})$ \\
\hline $\begin{array}{c}\text { convective pressure } \\
\text { at wall }\end{array}$ & $\mathrm{p}_{\mathrm{c}}(\varsigma, \theta, \mathrm{t})=\rho \sum_{\mathrm{n}=1}^{\infty} \psi_{\mathrm{n}} \cdot \cosh \left(\lambda_{\mathrm{n}} \gamma \varsigma\right) \cdot \mathrm{J}_{1}\left(\lambda_{\mathrm{n}}\right) \cdot \cos (\theta) \cdot \mathrm{A}_{\mathrm{cn}}(\mathrm{t})$ \\
\hline $\begin{array}{c}\text { convective pressure } \\
\text { on bottom }\end{array}$ & $\mathrm{p}_{\mathrm{c}}(\xi, \theta, \mathrm{t})=\rho \sum_{\mathrm{n}=1}^{\infty} \psi_{\mathrm{n}} \cdot \cosh \left(\lambda_{\mathrm{n}} \gamma\right) \cdot \mathrm{J}_{1}\left(\lambda_{\mathrm{n}} \xi\right) \cdot \cos (\theta) \cdot \mathrm{A}_{\mathrm{cn}}(\mathrm{t})$ \\
\hline \multicolumn{2}{|c|}{ pressure terms are defined in work $[2]$} \\
\hline
\end{tabular}

Table 3

\begin{tabular}{|c|c|}
\hline $\begin{array}{c}\text { impulsive pressure } \\
\text { at wall }\end{array}$ & $\mathrm{p}_{\mathrm{i}}=\mathrm{a} \cdot \rho \cdot \mathrm{h} \cdot\left[\frac{\mathrm{y}}{\mathrm{h}}-\frac{1}{2} \cdot\left(\frac{\mathrm{y}}{\mathrm{h}}\right)^{2}\right] \cdot \sqrt{3} \cdot \mathrm{th}\left(\sqrt{3} \cdot \frac{\mathrm{R} \cdot \cos (\Phi)}{\mathrm{h}}\right)$ \\
\hline $\begin{array}{c}\text { impulsive pressure } \\
\text { on bottom }\end{array}$ & $\mathrm{p}_{\mathrm{i}}=\mathrm{a} \cdot \rho \cdot \mathrm{h} \cdot \frac{\sqrt{3}}{2} \cdot \frac{\operatorname{sh}\left(\sqrt{3} \cdot \frac{\mathrm{x}}{\mathrm{h}}\right)}{\mathrm{ch}\left(\sqrt{3} \cdot \frac{1}{\mathrm{~h}}\right)}$ \\
\hline $\begin{array}{c}\text { convective pressure } \\
\text { at wall }\end{array}$ & $\mathrm{p}_{\mathrm{c}}=\delta \cdot \rho \cdot \mathrm{R} \cdot \frac{15}{16} \cdot \frac{\mathrm{k}_{1}}{\mathrm{~m}_{1}} \cdot\left(1-\frac{\cos ^{2}(\Phi)}{3}-\frac{\sin ^{2}(\Phi)}{2}\right) \cdot \cos (\Phi) \cdot \frac{\operatorname{ch}\left(\sqrt{\frac{27}{8}} \frac{\mathrm{h}-\mathrm{y}}{\mathrm{R}}\right)}{\mathrm{ch}\left(\sqrt{\frac{27}{8}} \frac{\mathrm{h}}{\mathrm{R}}\right)}$ \\
\hline $\begin{array}{c}\text { convective pressure } \\
\text { on bottom }\end{array}$ & $\mathrm{p}_{\mathrm{c}}=\delta \cdot \rho \cdot \mathrm{R} \cdot \frac{15}{16} \frac{\mathrm{k}_{1}}{\mathrm{~m}_{1}}\left(\frac{\mathrm{x}}{\mathrm{R}}\right)\left(1-\frac{1}{3}\left(\frac{\mathrm{x}}{\mathrm{R}}\right)^{2}-\frac{1}{2}\left(\frac{\mathrm{z}}{\mathrm{R}}\right)^{2}\right) \cdot \frac{1}{\mathrm{ch}\left(\sqrt{\frac{27}{8}} \frac{\mathrm{h}}{\mathrm{R}}\right)}$ \\
\hline \multicolumn{2}{|c|}{${ }^{\text {pressure terms are defined in work }[3]}$}
\end{tabular}

\section{Comparative study}

Two cylindrical tanks with the different functionalities in practice have been chosen: secondary settler (tank 1), fermentation tank (tank 2), having the same volume $\left(\mathrm{V}_{\mathrm{i}} \approx 5000 \mathrm{~m}^{3}\right)$, which stores water $\left(\gamma_{\mathrm{W}}=10 \mathrm{kN} / \mathrm{m}^{3}\right)$. It was considered that the wall is rigid in relation to the fluid and the seismic action is the same for both tanks, according to code P100-1/2013:

$\mathrm{a}_{\mathrm{g}}=0.2 \mathrm{~g}-$ design ground acceleration;

$\mathrm{T}_{\mathrm{c}}=0.7 \mathrm{~s}-$ corner period;

$\beta_{0}=2.5$ - factor of maximum dynamic amplification of the horizontal ground acceleration;

$\psi_{\mathrm{s}}=\frac{1}{\mathrm{q}}=0.35-$ behavior factor of the structure $[1,2]$. 
The geometric characteristics are considered as shown in Figure 4:
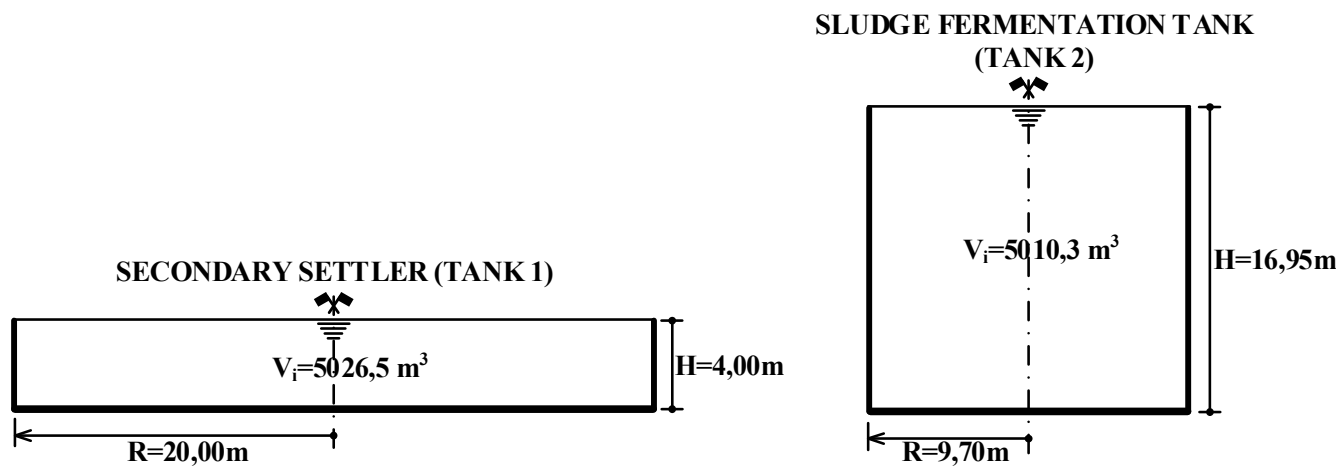

Fig. 4 - The specific geometry for each analyzed tank

In order to evaluate the hydrodynamic pressures for those two tanks, notations shown in [1] have been used, considering their variation mode according to Figure 5:
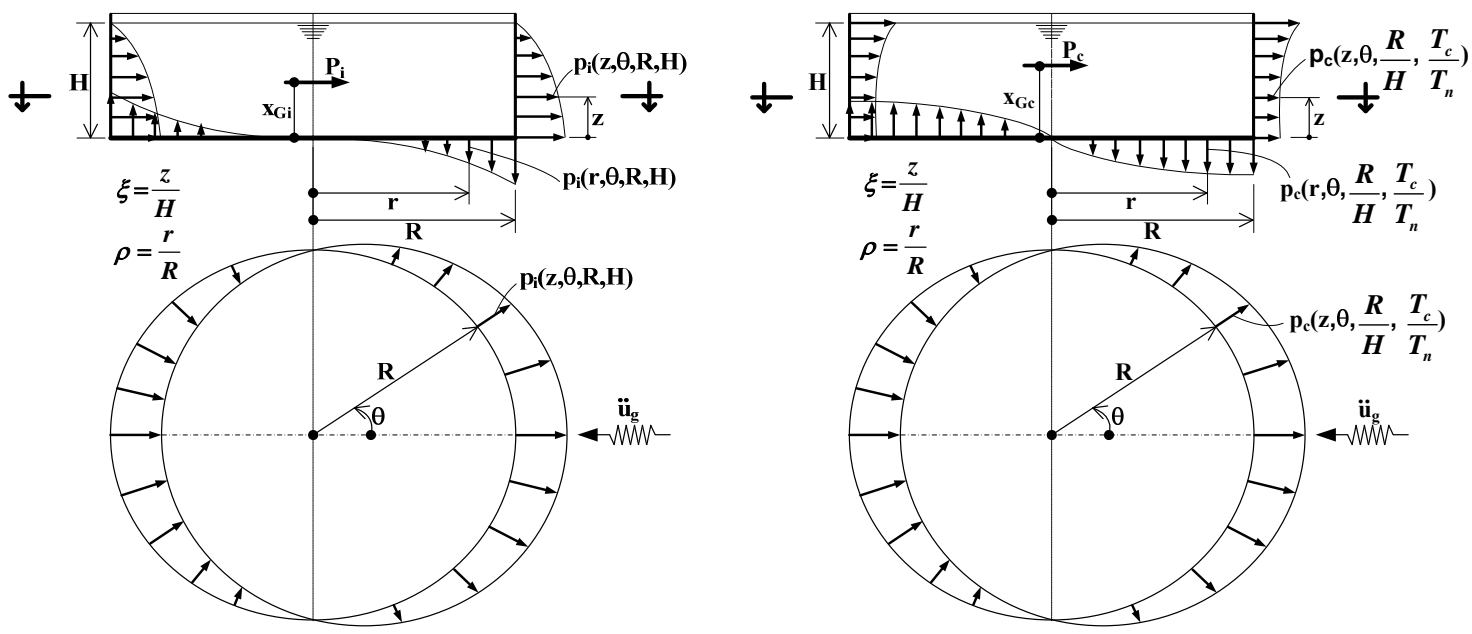

Fig. 5 - Geometrical notations and variation of hydrodynamic pressure impulsive and convective [1]

where:

$\mathrm{H}$ - height of water stored;

$\mathrm{R}$ - tank radius;

$\mathrm{r}, \theta, \mathrm{z}$ - cylindrical coordinate system of a point in the fluid mass;

$\xi, \rho$-nondimensional coordinates for cylindrical wall and foundation plate;

$\mathrm{u}_{\mathrm{g}}(\mathrm{t})$ - ground acceleration;

$\mathrm{T}_{\mathrm{n}}$ - natural period of sloshing;

$\mathrm{p}_{\mathrm{i}}(\mathrm{z}, \theta, \mathrm{R}, \mathrm{H})$ - hydrodynamic impulsive pressure at cylindrical wall;

$\mathrm{p}_{\mathrm{i}}(\mathrm{r}, \theta, \mathrm{R}, \mathrm{H})$ - hydrodynamic impulsive pressure on the tank bottom;

$\mathrm{p}_{\mathrm{c}}\left(\mathrm{z}, \theta, \frac{\mathrm{R}}{\mathrm{H}}, \frac{\mathrm{T}_{\mathrm{c}}}{\mathrm{T}_{\mathrm{n}}}\right)$ - hydrodynamic convective pressure at cylindrical wall;

$\mathrm{p}_{\mathrm{c}}\left(\mathrm{r}, \theta, \frac{\mathrm{R}}{\mathrm{H}}, \frac{\mathrm{T}_{\mathrm{c}}}{\mathrm{T}_{\mathrm{n}}}\right)$ - hydrodynamic convective pressure on the tank bottom;

$\mathrm{P}_{\mathrm{i}}$ - hydrodynamic impulsive pressure resultant at cylindrical wall; 
$\mathrm{P}_{\mathrm{c}}$ - hydrodynamic convective pressure resultant at cylindrical wall;

$\mathrm{x}_{\mathrm{Gi}}$ - lever arm which corresponds resultant of hydrodynamic impulsive pressure;

$\mathrm{x}_{\mathrm{Gc}}-$ lever arm which corresponds resultant of hydrodynamic convective pressure;

$\mathrm{M}_{\mathrm{i}}$ - impulsive global moment including the effect of wall and slab pressures;

$\mathrm{M}_{\mathrm{c}}$ - convective global moment including the effect of wall and slab pressure;

Using the geometry from Figure 4, the notations from Figure 5 and the seismic characteristics shown above, the impulsive and convective hydrodynamic pressures were determined, both on the wall and bottom cylindrical tank, following the proposals of rules from these works:

- G.W. Housner's proposal from treatise "Şocuri și Vibrații - Cyril M. Harris și Charles E. Crede" [3];

- proposal from book “Dinamica plăcilor plane și curbe - D. Furiș, G. Groza” [1];

- proposal from work "SR EN 1998-4" [2].

Additionally, the resultants of hydrodynamic pressures were determined (horizontal forces and bending moments) using Epstein's model from paper [5].

It should be specified that in SR EN 1998-4 there is a note: "Only the first oscillating, or sloshing mode and frequency of the oscillating liquid $(n=1)$ needs to be considered in expression (A.7) for design purposes", referring to the determination of the convective hydrodynamic pressure.

G.W. Housner and H.I. Epstein, using simplified models, determine the convective hydrodynamic pressure using the fundamental period of oscillation, while the specialized paper [1] considers the first ten periods of oscillation.

The principles for dynamic equivalence between the models presented in [1], [2] and the simplified models made by G.W. Housner [3] and H.I. Epstein [5] describing the fluid mass movement are:

- the force of inertia corresponding to the impulsive mass from works [3], [5], must be equal to the resultant of the hydrodynamic impulsive pressure calculated with the relations from [1], [2];

- the force of inertia corresponding to the convective mass from works [3], [5], must be equal to the resultant of hydrodynamic convective pressure calculated with relations from [1], [2], and the fundamental period of oscillation of the fluid mass from [1], [2], must be equal to the period of the simplified dynamic system from [3], [5].

It must also be specified the wide variation of the eigenperiods (natural periods) of the fluid. In the analyzed cases, the first ten natural periods of oscillation of the fluid mass are listed in the following table:

\begin{tabular}{|c|c|c|c|c|c|c|c|c|c|c|}
\hline & & & & & & & & & & Table \\
\hline $\mathbf{T}_{\mathrm{n}}[\mathbf{s}]$ & $\mathbf{T}_{1}$ & $\mathbf{T}_{2}$ & $\mathbf{T}_{3}$ & $\mathbf{T}_{4}$ & $\mathbf{T}_{5}$ & $\mathbf{T}_{6}$ & $\mathbf{T}_{7}$ & $\mathbf{T}_{8}$ & $\mathbf{T}_{9}$ & $T_{10}$ \\
\hline Secondary settler (tank 1) & 11.138 & 4.377 & 3.173 & 2.647 & 2.333 & 2.115 & 1.950 & 1.820 & 1.712 & 1.622 \\
\hline Sludge fermentation tank (tank 2) & 4.612 & 2.706 & 2.138 & 1.826 & 1.621 & 1.472 & 1.358 & 1.267 & 1.192 & 1.129 \\
\hline
\end{tabular}

Their natural periods listed in Table 4 were obtained with the relations from paper [1]:

$$
\begin{aligned}
& \mathrm{T}_{\mathrm{n}}=\frac{2 \pi}{\omega_{\mathrm{n}}} \\
& \omega_{\mathrm{n}}=\sqrt{\lambda_{\mathrm{n}} \frac{\mathrm{g}}{\mathrm{R}} \tanh \left(\lambda_{\mathrm{n}} \frac{\mathrm{H}}{\mathrm{R}}\right)}-\text { circular frequency of the fluid; }
\end{aligned}
$$


$\lambda_{\mathrm{n}}-$ roots of equation $\frac{\mathrm{dJ}_{1}(\mathrm{x})}{\mathrm{dx}}=0$

\begin{tabular}{|c|c|c|c|c|c|c|c|c|c|c|}
\hline $\mathbf{n}$ & $\lambda_{1}$ & $\lambda_{2}$ & $\lambda_{3}$ & $\lambda_{4}$ & $\lambda_{5}$ & $\lambda_{6}$ & $\lambda_{7}$ & $\lambda_{8}$ & $\lambda_{9}$ & $\lambda_{10}$ \\
\hline$\lambda_{\mathbf{n}}$ & 1.841 & 5.331 & 8.536 & 11.706 & 14.863 & 18.015 & 21.166 & 24.311 & 27.475 & 30.601 \\
\hline
\end{tabular}

In paper [5] a simplified relationship for determining the fundamental period of oscillation of the fluid is shown:

$$
\mathrm{T}=4.65 \sqrt{\frac{\mathrm{R}}{\mathrm{g}}}
$$

Using equation (9), the fundamental oscillation periods of fluid are:

- $\quad$ secondary settler (tank 1), $\mathrm{T}=6.639 \mathrm{~s}$;

- $\quad$ sludge fermentation tank ( $\operatorname{tank} 2), \mathrm{T}=4.624 \mathrm{~s}$.

It is notable that although the algorithm of SR EN 1998-4 [2] is similar to the algorithm presented in [1], the first uses for the determination of the hydrodynamic impulsive pressure the first order modified Bessel function, $\mathrm{I}_{1}(\mathrm{x})$, while the second uses the Bessel function of the first kind and first order, $\mathrm{J}_{1}(\mathrm{x})$.

In the comparisons below, to show the differences and answer the question of to be or not to be sufficient to use only the fundamental period of oscillation, both results of the convective pressure were graphically represented considering the first mode of oscillation and those obtained with ten modes of oscillation as shown in [1].

There were determined total pressures $\left(\mathrm{p}_{\mathrm{i}}+\mathrm{p}_{\mathrm{c}}\right)$ and horizontal forces, bending moments as resultants of hydrodynamic pressure given by pressures from wall and bottom of the tank.

The numerical comparisons are presented in the graphs below:
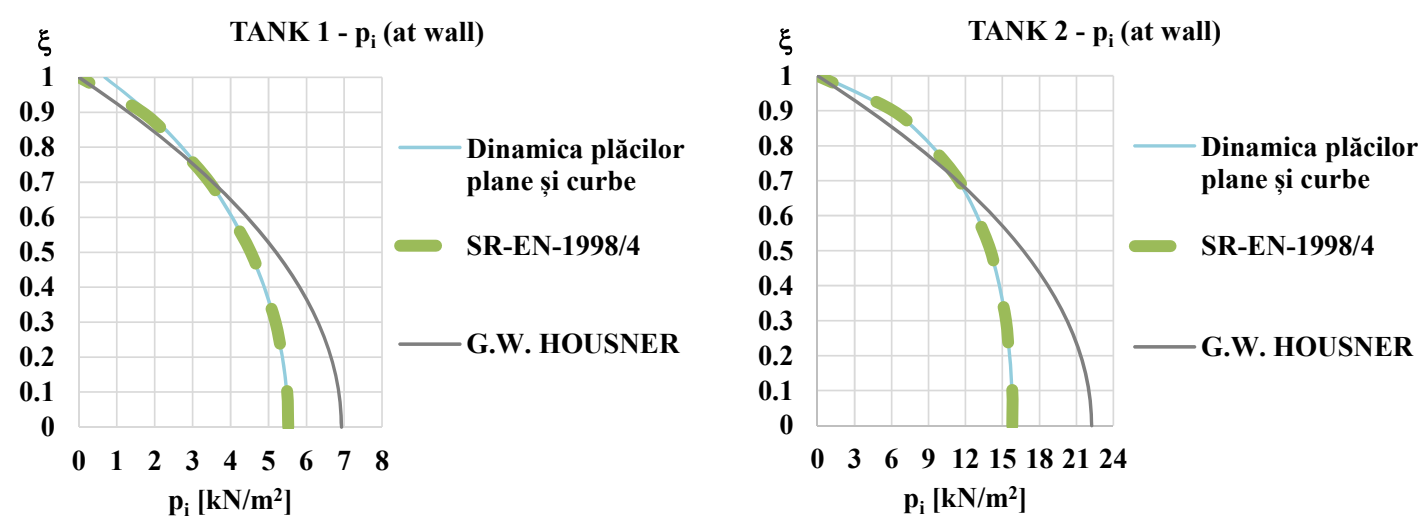

Fig. 6 - Impulsive pressure at tank wall (TANK 1 and TANK 2)
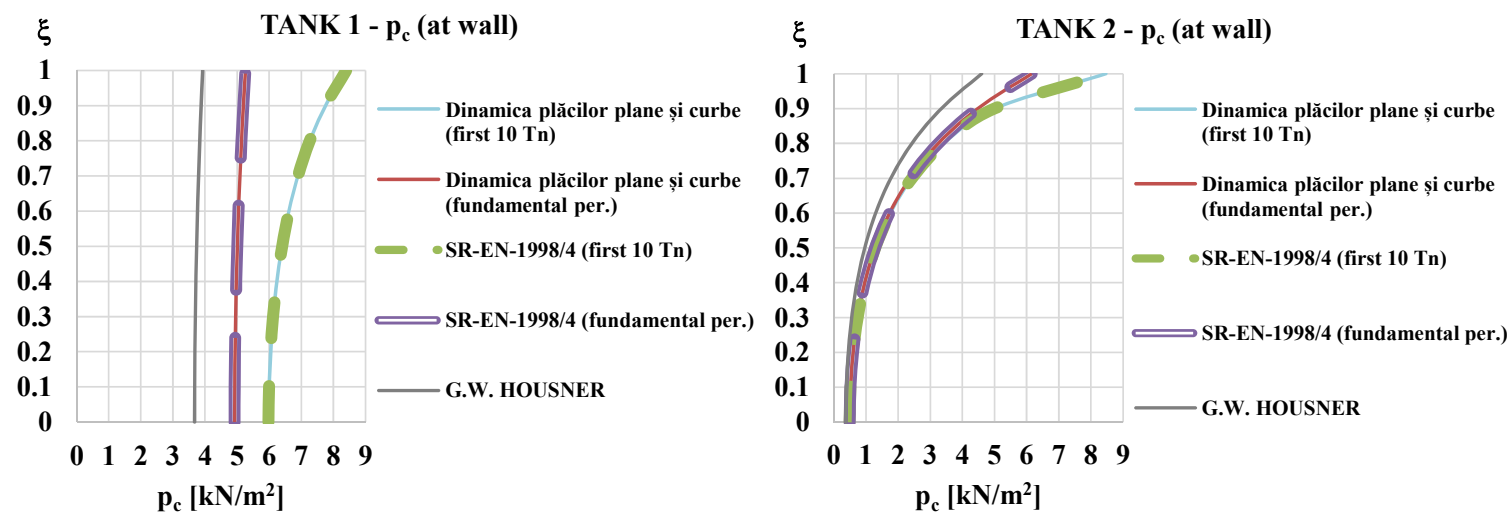
Fig. 7 - Convective pressure at tank wall (TANK 1 and TANK 2)
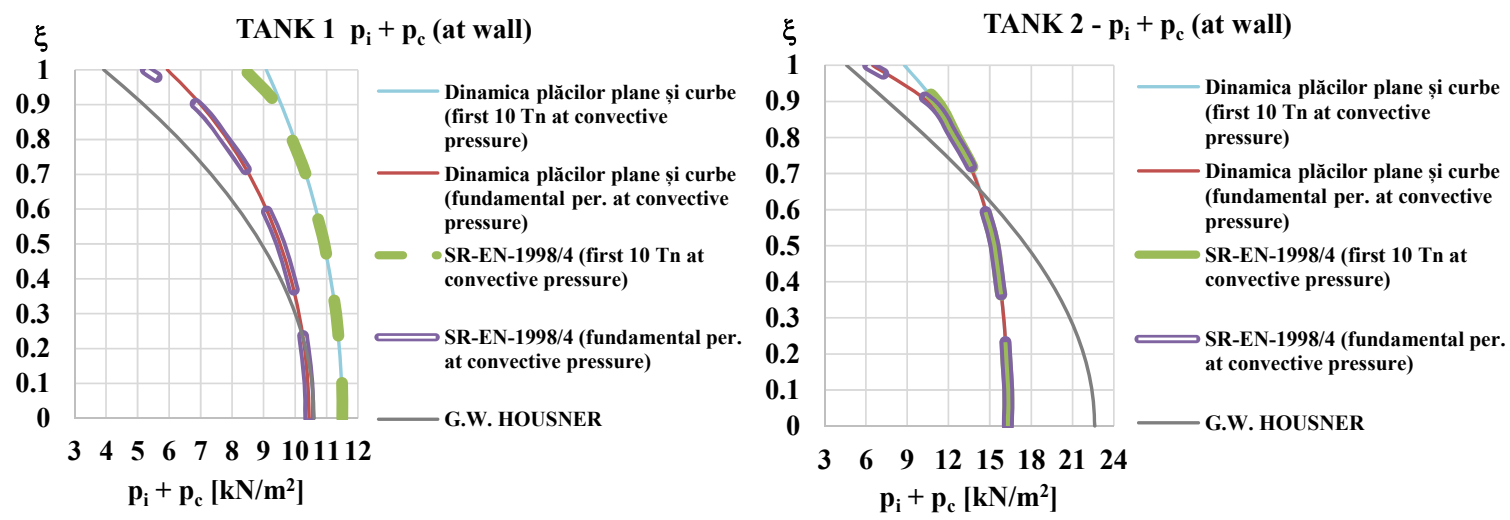

Fig. 8 - Total pressure at tank wall (TANK 1 and TANK 2)

TANK 1 - $\mathbf{p}_{\mathrm{i}}$ (on bottom)

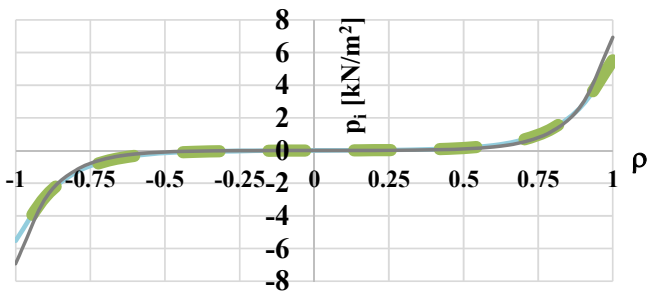

_Dinamica plăcilor plane și curbe

SR-EN-1998/4

G.W. HOUSNER
TANK 2 - $\mathbf{p}_{\mathrm{i}}$ (on bottom)

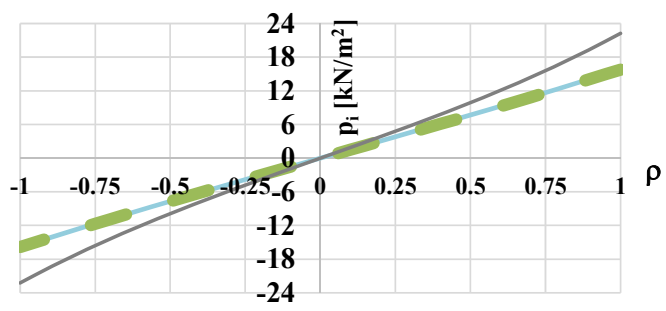

Dinamica plăcilor plane și curbe

SR-EN-1998/4

G.W. HOUSNER

Fig. 9 - Impulsive pressure on bottom tank (TANK 1 and TANK 2)

TANK 1 - p (on bottom)

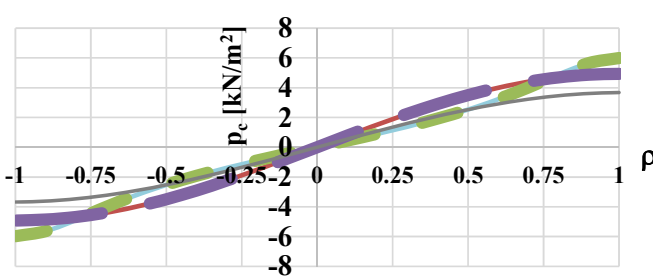

Dinamica plăcilor plane și curbe (first 10 Tn)

Dinamica plăcilor plane și curbe (fundamental per.)

SR-EN-1998/4 (first 10 Tn)

SR-EN-1998/4 (fundamental per.)

G.W. HOUSNER
TANK 2 - $p_{c}$ (on bottom)

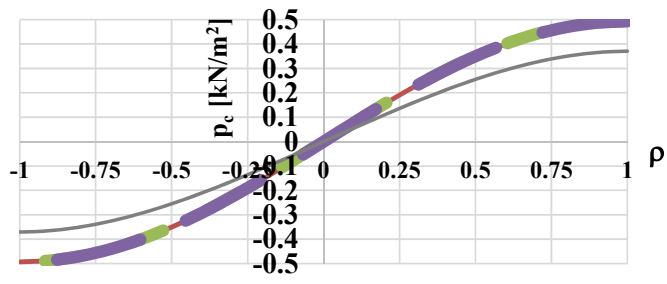

Dinamica plăcilor plane și curbe (first $10 \mathrm{Tn}$ )

_Dinamica plăcilor plane și curbe (fundamental per.)

- SR-EN-1998/4 (first 10 Tn)

SR-EN-1998/4 (fundamental per.)

G.W. HOUSNER

Fig. 10 - Convective pressure on bottom tank (TANK 1 and TANK 2)

TANK $1-p_{i}+p_{c}$ (on bottom)

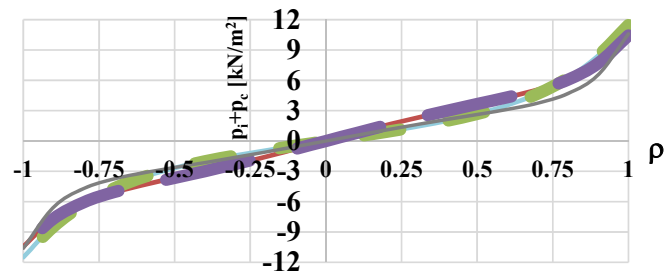

Dinamica plăcilor plane și curbe (first $10 \mathrm{Tn}$ )

Dinamica plăcilor plane și curbe (fundamental per.)

SR-EN-1998/4 (first 10 Tn)

SR-EN-1998/4 (fundamental per.)

G.W. HOUSNER
TANK $2-p_{i}+p_{c}$ (on bottom)

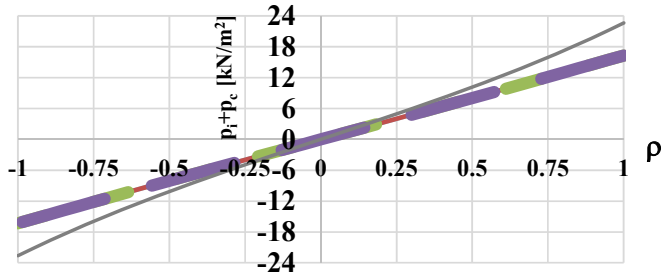

Dinamica plăcilor plane și curbe (first 10 Tn)

—Dinamica plăcilor plane și curbe (fundamental per.)

SR-EN-1998/4 (first 10 Tn)

SR-EN-1998/4 (fundamental per.)

- G.W. HOUSNER

Fig. 11 - Total pressure on bottom tank (TANK 1 and TANK 2) 


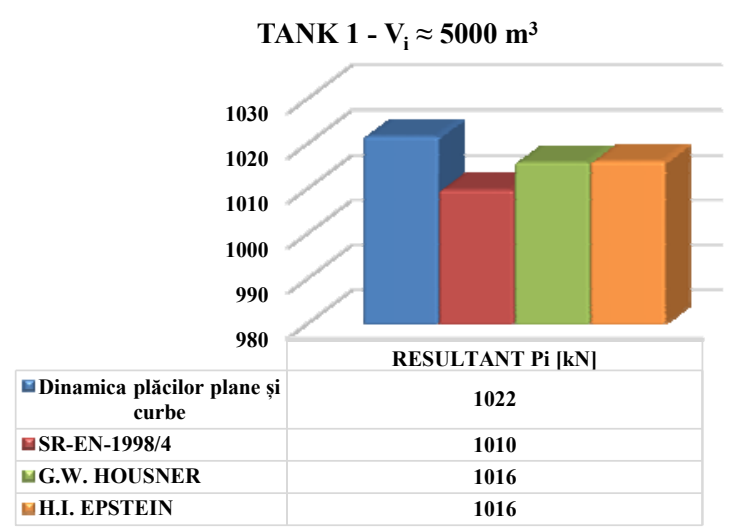

TANK $1-\mathrm{V}_{\mathrm{i}} \approx 5000 \mathrm{~m}^{3}$

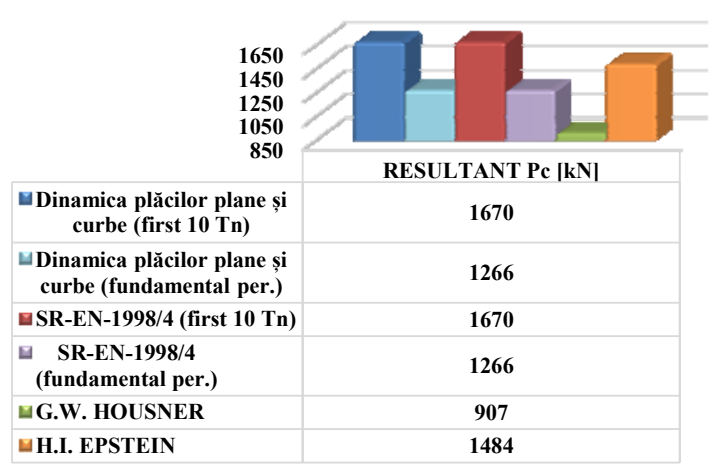

TANK $1-V_{\mathrm{i}} \approx 5000 \mathrm{~m}^{3}$

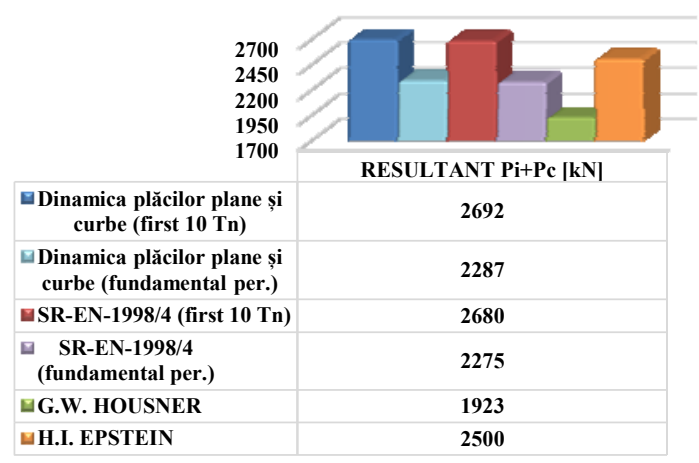

TANK $1-\mathrm{V}_{\mathrm{i}} \approx 5000 \mathrm{~m}^{3}$

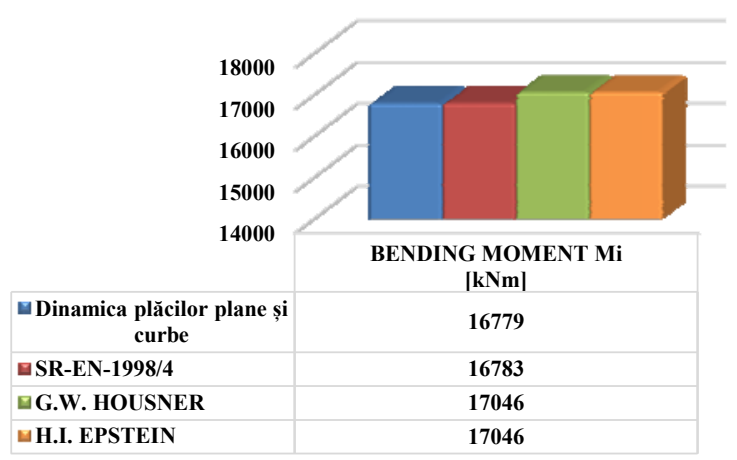

TANK $2-\mathrm{V}_{\mathrm{i}} \approx 5000 \mathrm{~m}^{3}$

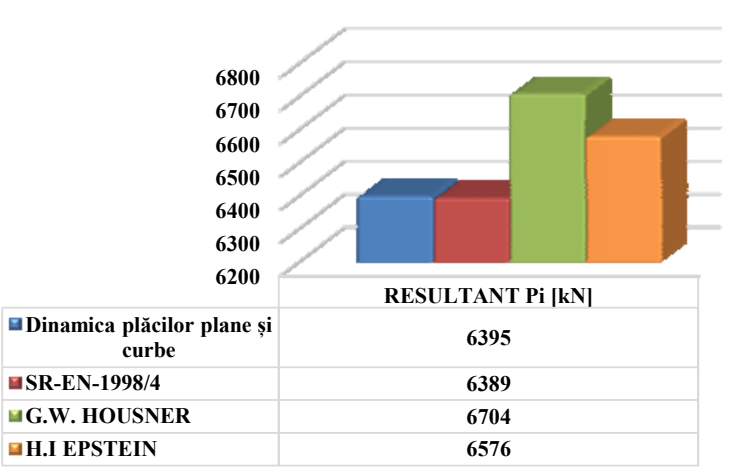

TANK $2-\mathrm{V}_{\mathrm{i}} \approx 5000 \mathrm{~m}^{3}$

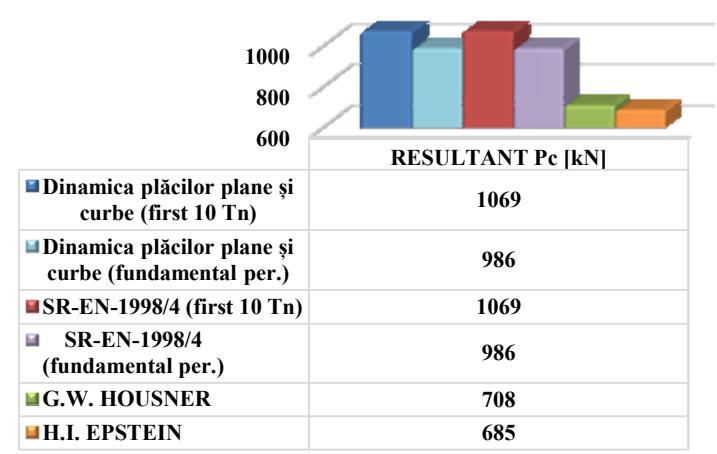

TANK $2-\mathrm{V}_{\mathrm{i}} \approx 5000 \mathrm{~m}^{3}$

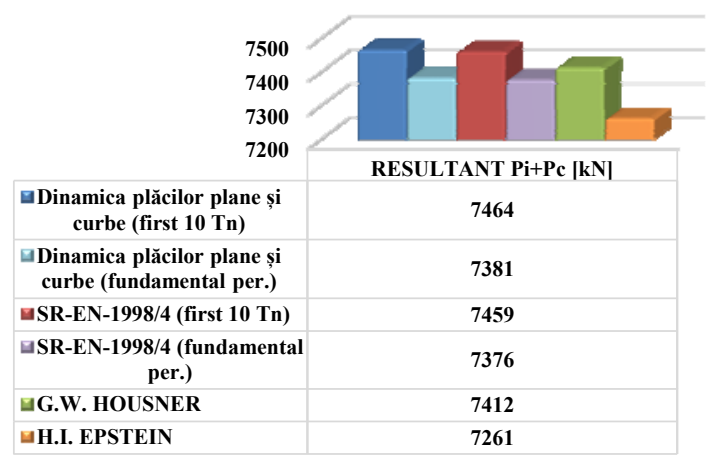

TANK $2-\mathrm{V}_{\mathrm{i}} \approx 5000 \mathrm{~m}^{3}$

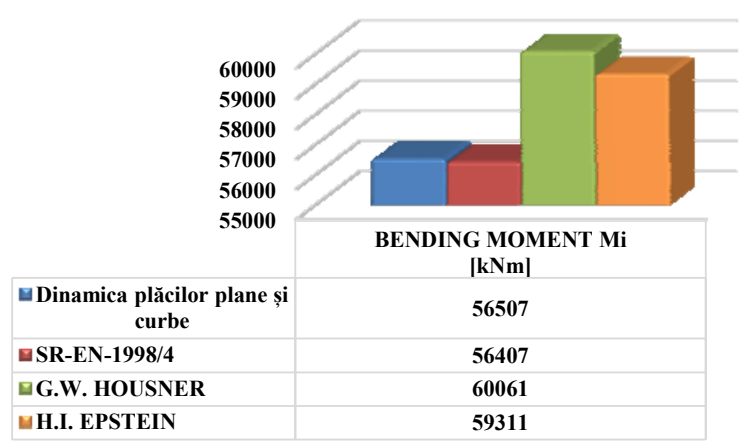




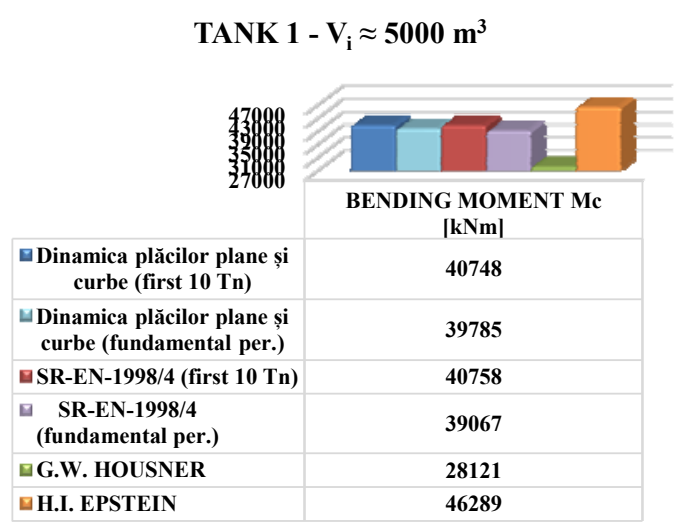

TANK $1-V_{\mathrm{i}} \approx 5000 \mathrm{~m}^{3}$

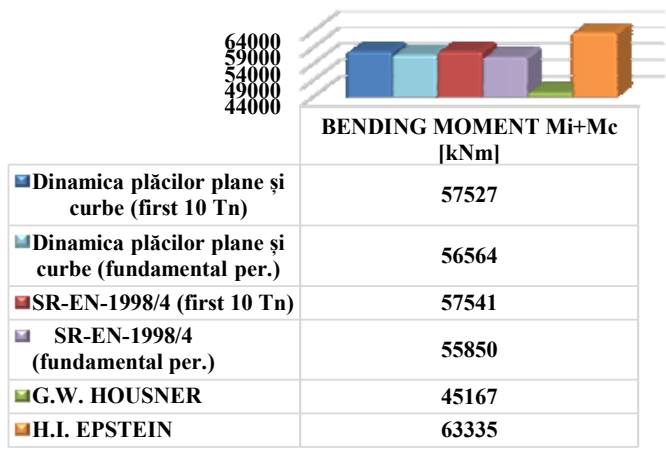

TANK $2-\mathrm{V}_{\mathrm{i}} \approx 5000 \mathrm{~m}^{3}$

\begin{tabular}{|c|c|}
\hline & \\
\hline $\begin{array}{c}\square \text { Dinamica plăcilor plane și } \\
\text { curbe (first 10 Tn) }\end{array}$ & 13626 \\
\hline $\begin{array}{c}\text { Dinamica plăcilor plane și } \\
\text { curbe (fundamental per.) }\end{array}$ & 12337 \\
\hline$\square$ SR-EN-1998/4 (first 10 Tn) & 13626 \\
\hline $\begin{array}{c}\text { SR-EN-1998/4 } \\
\text { (fundamental per.) }\end{array}$ & 12337 \\
\hline$\square$ G.W. HOUSNER & 8859 \\
\hline G.I. EPSTEIN & 8888 \\
\hline
\end{tabular}

TANK $2-V_{i} \approx 5000 \mathbf{m}^{3}$

\begin{tabular}{|c|c|}
\hline $\begin{array}{l}70000 \\
69000 \\
68000\end{array}$ & $\begin{array}{c}\text { BENDING MOMENT Mi+Mc } \\
{[\mathrm{kNm}]}\end{array}$ \\
\hline $\begin{array}{l}\text { Dinamica plăcilor plane și } \\
\text { curbe (first } 10 \text { Tn) }\end{array}$ & 70133 \\
\hline $\begin{array}{l}\square \text { Dinamica plăcilor plane și } \\
\text { curbe (fundamental per.) }\end{array}$ & 68844 \\
\hline$\square$ SR-EN-1998/4 (first 10 Tn) & 70033 \\
\hline $\begin{array}{c}\text { SR-EN-1998/4 } \\
\text { (fundamental per.) }\end{array}$ & 68744 \\
\hline 匹G.W. HOUSNER & 68920 \\
\hline E.I. EPSTEIN & 68199 \\
\hline
\end{tabular}

\section{Conclusions}

By analyzing how the variation of hydrodynamic pressures acts on walls, the following comments can be considered:

- papers [1] and [2] provide approximately the same values of total hydrodynamic pressure $\left(\mathrm{p}_{\mathrm{i}}+\mathrm{p}_{\mathrm{c}}\right)$, in case of tank $2(\mathrm{R} / \mathrm{H}=0.57)$ insignificant differences between using the first period of oscillation of the fluid mass and ten periods of oscillation can be seen;

- with increasing of the $\mathrm{R} / \mathrm{H}$ rate, differences between considering in the calculation of the convective pressure first period of the oscillation or the first ten periods of oscillation are significant: in tank $1(\mathrm{R} / \mathrm{H}=5)$, in section $\xi=1$ a difference of about $38 \%$ is reached, while in section $\xi=0$ the differences are about $9.2 \%$;

- the hydrodynamic pressure distribution by Housner's model differs according to the works [1] and [2], because of the simplified calculation that is the basis of this method.

Regarding the variation of hydrodynamic pressures on the tank bottom, the results obtained with the calculation methods supply approximately the same values for the convective pressure, no matter if the fundamental period or ten periods of oscillation of the fluid mass are considered.

Analyzing the values of the total hydrodynamic pressure, significant differences (about $15 \%$ in case of tank 1) between taking into account the first ten periods of oscillation and those obtain with other calculation models can be noticed.

Regarding the bending moments for big ratio $\mathrm{R} / \mathrm{H}$, the differences are insignificant, but in the case of tank $2(\mathrm{R} / \mathrm{H}=0.57)$ there are very big differences between the results obtained with the first ten periods and those obtained with other models. 
Simplified models with two or three masses, made by G.W. Housner and H.I. Epstein to find resultants, are based on the principles of dynamic equivalence, and the results of these can be considered satisfactory.

Certainly, in practice every designer is responsible for the way he takes the problem of evaluating hydrodynamic pressure, but it should be specified that, although the simplifying hypotheses and boundary conditions are the same for all the analyzed works, the results considering the fundamental period or ten periods of oscillation of fluid mass can vary a lot, and the differences are also reflected in the values of internal forces. Also the checks for tank overturning effect and evaluation of pressures on the ground can be affected by these differences.

\section{References}

[1] Furiş D., Groza G. (2000). Dinamica plăcilor plane și curbe. Ed. Conspress, București;

[2] SR EN 1998-4 (2007). Eurocod 8: Proiectarea structurilor pentru rezistența la cutremur - Partea 4: Silozuri, rezervoare și conducte;

[3] Harris C. M., Crede Ch. E. (1969). Șocuri şi vibrațiii. Ed. Tehnică, București (translated from english);

[4] P100-1 (2013). Cod de proiectare seismică - Partea I - Prevederi de proiectare pentru clădiri. București;

[5] Hampe E. (1982). Flüssigkeitsbehälter, Band 2 Bauwerke, Berlin;

[6] Prișcu R., Popovici A., Stematiu D., Ilie L., Stere C. (1978). Inginerie seismică pentru construcții hidrotehnice, București; 